\title{
Personality Traits and Psychological Symptoms of Music and Art Students
}

\author{
Sadık Yöndem ${ }^{1}$, Zeynep Deniz Yöndem ${ }^{1}$, Meral Per ${ }^{1}$ \\ ${ }^{1}$ Abant Izzet Baysal University, Turkey \\ Correspondence: Sadık Yöndem, Abant Izzet Baysal University, Faculty of Education, Turkey.
}

Received: May 21, 2017

Accepted: June 11, 2017

Online Published: June 15, 2017

doi:10.11114/jets.v5i7.2431

URL: https://doi.org/10.11114/jets.v5i7.2431

\begin{abstract}
The qualities of artists and musicians have attracted the attention of personality psychologists and researchers studying creativity. Artistic activities are considered by some to be therapeutic, and may offer a buffer effect on psychological health. On the other hand, research has occasionally revealed a positive relationship between creativity and psychological disorders when it comes to artistic activities. This study aims to investigate the personality traits and psychological symptoms of art and music students, and to make comparisons between different fields of art. The present research was planned as a descriptive and comparative study. The participants consisted of 245 university students (79 male, and 166 female), including 120 music and 125 art students. The Big Five Inventory, the Brief Symptom Inventory, and a Personal Information Form were administered to all participants. The Mann-Whitney U test, a descriptive analysis method, was used to test if students from the two fields of art differed according to their personality traits and psychological symptoms. The results showed that the students from both fields of art had a similar range of scores for the five domains of personality traits: extroversion, openness to new experiences, agreeableness, conscientiousness, and neuroticism. The study revealed that neuroticism in the music students and conscientiousness in art students were found to be significantly higher. As for psychological symptoms, the music students' scores on total symptom disorder, anxiety, and negative self-concept factors were found to be significantly higher than that of art students. The results of the study were discussed by drawing upon relevant literature.
\end{abstract}

Keywords: personality traits, psychological symptoms, art students, music students

\section{Introduction}

Personality is a very comprehensive concept, encompassing features such as an individual's interests, talents, attitudes, external appearance, and adaptation to the environment (Baymur, 1994). Personality psychologists suggest that some behavioral patterns of personality traits show continuity and consistency over time, and that they may be based on a combination of early childhood experiences and evolutionary and biological factors (Yöndem, 2015). Efforts in the measurement and identification of personality traits in psychology have become a focus of interest for many researchers from differing fields. It is assumed in Holland's theory of vocation that personality traits determine vocational choices, and that people working in the same field show similar personality traits (Çakır, 2014). Research conducted based on Jung's typology theory (Kuzgun \& Deryakulu, 2004) also posits that intuitive type people tend to gravitate toward art-related professions.

Some of the initial studies in which artists, usually defined by their creative personality traits, were compared with non-artists revealed that artists have more extraordinary thinking styles and different reality perception manners; they also have more dominant, adventurous, and bohemian personalities (Eiduson, 1957; Drevdahl \& Cattell, 1958). Dutta Roy (1996) compared artists with non-artists using Cattel's 16 Personality Factors Test, and reported that artists are more introverted, independent, and tender-minded than others. Feist (1998), in a comprehensive meta-analytic study that compared artists with non-artists, reported that artists are: more open to new experiences, less conventional, fairer, more self-confident, more motivated and ambitious, dominant, impulsive, and more hostile. It was stated in the manual of the Eysenck Personality Questionnaire that students in artistics field have higher than average levels of psychoticism and neuroticism, and it was also stated in Eysenck's theory of personality that creativity is associated with psychoticism dimension rather than neuroticism (Booker, Feam \& Francis, 2001).

Research literature centering on artistic personalities has a tendency to express some specific features that describe the personality traits of individuals in the field of music and the visual arts. Kemp (1996) compared the personality traits of music students, professional musicians, and non-musicians, and determined that musicians are more introverted. Dyce 
and O'Connor (1994) compared rock and country musicians with a similar sample group consisting of male university students, and reported that musicians are more arrogant, dominant, extroverted, open to experiences, and more neurotic than non-musicians. The authors emphasized that neuroticism may be necessary in some musical performances, since this trait tends to increase the emotional and dramatic aspects of a musician's performance. Cribb and Gregory (1999) compared the personality types of orchestral musicians using Eysenck's Personality Inventory and found that neurotic features are more common in string players, while wind players tend to be more good-tempered and less afraid of taking risks. Vuust and colleagues (2010) compared students studying classical music and those studying rhythms in Denmark Music Academy. They revealed that students studying rhythms scored significantly higher in the category of sensation seeking than those studying classical music. On the other hand, classical students state anxiety level were higher than rhythmic students. Additionally, Steele and Young (2011) compared the personality types of undergraduate music education students with that of music therapy students using the Myers-Briggs Personality Test (MBTI). They found that music education students tend to be more extroverted than music therapy students. They also stated that the personality types of music education students were identified as extroverted, intuitional, emotional, and judgmental. Furthermore, Cameron, Duffy, and Glenwright (2014) investigated the personality traits of pop musicians (bass guitarists, drummers, guitarists, and vocalists) by using the Big Five Inventory and found that vocalists are more extroverted than bass guitarists.

It is interesting to note that musicians have mostly been the subject of related literature. They were evaluated based on their personality traits. The personality traits of individuals interested in the visual arts, on the other hand, have not been as thoroughly examined. However, studies have generally focused on the relationship between creativity and psychopathological features including individuals interested in the visual arts. Carson (2011) stated that people with high creativity levels are in the risk group for pathological features such as depression, schizophrenia, and alcoholism. Additionally, Ludwig (1998) reported relationships between different fields of art, especially the visual artists and some mental illnesses in 137 well-known artist sample. Booker, Feam \& Francis (2001) also determined that male and female artists obtained higher scores in the personality dimensions of neuroticism and psychoticsm than non-artists. Rawlings and Locarnini (2008) compared 31 professional visual artists and musicians with 28 professionals from differing disciplines and reported that schizotypal and manic features (positive schizotypy and hypomania) were higher in professional artists and musicians. Burch, Pavelis, Hemsley, and Corr (2006) found that visual artists have more positive-schizotypy, neuroticism, openness, and divergent thinking but less agreeableness than non-artist samples. Furthermore, in a study of professional artists and sculptors in West Germany, Götz and Götz (1979) found that both male and female artists scored higher on psychosis scale than non-artists. They also found that male artists scored higher on neuroticism than non-artists. Clarke \& Gipe (1989) studied with artists/teachers providing training for visual and performance arts in high schools and found that they held highly intuitive and judgmental personality characteristics, but they were not specifically introverted or extroverted. Per \& Beyoğlu (2011) compared students in mathematics, the social sciences, and art students (painters) and found that extroversion, intuition, and judgment were higher in art students than in students studying mathematics and the social sciences, according to the Myers Briggs Type Indicator.

This study aimed to investigate and compare the personality traits and psychological symptoms of art and music students. In this context, two research questions were examined: 1) What kinds of patterns in personality traits and psychological symptoms emerge in art and music students? ; and 2) Do art and music students differ in terms of personality traits and psychological symptoms?

\section{Method}

Descriptive and comparative research methods were used to determine personality traits and psychological symptoms, and to compare art and music students according to the aforementioned variables.

Participants: The participants of this study consisted of 245 university students (79 male, 166 female) including 120 music students (49\%) and 125 art students (51\%) studying as teacher candidates in the Fine Arts Education Department of the Faculty of Education in Abant Izzet Baysal University, Turkey. The average participant age was 21.07 (SD=2.58) with the range between 18 to 32 . The participants' grade standings at the time of the study were as follows: 25 (10.2\%) were freshman (first-year students), 54 (22\%) were sophomores (second year), 84 (34.3\%) were juniors (third year), and $82(33.5 \%)$ were seniors (fourth year).

Big Five Inventory (BFI): The Turkish form of the Big Five Inventory (Evinç, 2004) was used to determine personality traits. The scale was tested in terms of validity and reliability; it has been used in many different sampling groups throughout Turkey. It is a self-report scale consisting of 44 items that are rated using a five-point Likert type scale (1: strongly disagree to 5: strongly agree). The BFI evaluates personality traits including extraversion (being sociable, assertive, energetic, adventurous, and outgoing), agreeableness (having trust, straightforwardness, warmth, 
modesty, and sympathetic), conscientiousness (being competent, organized, dutiful, goal driven, and self-disciplined), neuroticism (having anxiety, hostility, depression, timidity, lack of self-confidence), and openness to new experiences (being curious, imaginative, artistic, excitable, and unconventional) (John \& Srivastava, 1999). High scores from the sub-scales reflect that the relevant personality trait is more prominent. The Cronbach alpha consistency reliability coefficients of the subscales in this study's samples were as follows: .79 for openness to new experiences, .73 for extraversion, .71 for conscientiousness, .71 for neuroticism, and .64 for agreeableness.

Brief Symptom Inventory (BSI): The Turkish form of the BSI (Şahin \& Durak, 1994, in Savaşır \& Şahin, 1997), a brief form of Symptom Check List-SCL-90R developed by Derogatis in 1992, was used to identify the psychological symptoms. The scale is widely used to determine psychological disorders in clinical and normal samples. The scale is a self-report Likert-type scale consisting of 53 items, scored between 0-4 (0: none and 4: too many). There are nine subscales in the original form of the scale, and five subscales in the Turkish form including anxiety (13 items; tension, fear, anxiety and panic states), depression (12 items; pessimism, unhappiness, and unwillingness states), negative self-concept (12 items; inadequacy, worthlessness, and a lack of self-confidence), somatization (9 items; somatic complaints such as shortness of breath and digestive problems), and hostility ( 7 items; nervousness, anger, violence). High scores from the subscales reflect the frequency of the symptoms in the relevant facet of the individual. In this study, in addition to the subscale scores, the total symptom disorder scores (the score obtained from all of the items on the scale) were also added to the analyses. In the adaptation study of the scale, the criterion-related validity and factor analysis methods were used. The Cronbach alpha internal consistency reliability coefficient was reported as .96 for the whole scale, and ranged between .55 and .86 for the subscales (Savaşır \& Şahin, 1997). The Cronbach alpha reliability coefficients of this study sample were calculated as .87 for anxiety, .88 for depression, .88 for negative self-concept, .84 for somatization, .77 for hostility, and .96 for the total symptom disorder.

Personal-Information Form: Information, including age, gender, and participant grade level, was collected for research purposes by using the Personal Information Form prepared by the researchers.

\section{Collection of Data}

In the data gathering process, the scales were administered collectively in classrooms with the permission of the course instructors. Explanations of the study's aim, privacy policy, and willingness of participants were both written and verbally delineated. The scales were completed in approximately 15 minutes.

\section{Analysis of Data}

The research data was analyzed using the SPSS 20 computer program. Before the analyses, data was screened and prepared for the analysis. The average value assignment method was used for data with few missing values. In the data analyses, the normal distribution of the scores of the personality traits and psychological symptoms were primarily tested using the Kolmogorov-Smirnov normality test for the related research variables. A normal distribution was observed only in the conscientiousness and neuroticism sub-dimensions from the BFI. Therefore, the Mann-Whitney U test, a nonparametric technique, was used for comparing the personality traits and psychological symptoms of music and art students.

\section{Results}

Table 1 below demonstrates the results of the descriptive analysis for the personality traits and psychological symptoms for music students and art students. It was found that music and art students' personality traits ranked similarly according to the Big Five Personality traits: extraversion-E $(M=5.83$; $S D=63$ for Music and $M=5.82 ; S D=.56$ for art students ); openness to new experiences- $\mathrm{O}(\mathrm{M}=3.95 ; \mathrm{SD}=.56$ for music and $\mathrm{M}=4.04 ; \mathrm{SD}=.53$ for art students); agreeableness- $\mathrm{A}(\mathrm{M}=3.82 ; \mathrm{SD}=.53$ for music and $\mathrm{M}=3.82 ; \mathrm{SD}=.53$ for art students); conscientiousness- $\mathrm{C}(\mathrm{X}=3.35$; $\mathrm{SD}=.61$ for music and $\mathrm{M}=3.49 ; \mathrm{SD}=.59$ for art students); and neuroticism-N ( $\mathrm{M}=3.26 ; \mathrm{SD}=.70$ for music and $\mathrm{M}=3.03$; $\mathrm{SD}=.67$ for art students). Additionally, art students were found to have significantly higher scores ( $<<.05)$ in conscientiousness $(\mu=6391.000 ; Z=2.003 ; p=.045)$, and music students were significantly higher scores in neuroticism $(\mu=5958.000 ; Z=2.785 ; p=.005)$ (see table 2). There were no significant differences between music and art students for extraversion, agreeableness and openness to new experiences traits.

The psychological symptoms of music and art students were ranked as depression-D (M=1.54; $\mathrm{SD}=.94$ for music and $\mathrm{M}=1.31 ; \mathrm{SD}=.83$ for art students), hostility- $\mathrm{H}(\mathrm{M}=1.50 ; \mathrm{SD}=.91$ for music and $\mathrm{M}=1.27 ; \mathrm{SD}=1.27$ for art students), anxiety-A $(\mathrm{M}=1.18 ; \mathrm{SD}=.79$ for music and $\mathrm{M}=.91 ; \mathrm{SD}=.67$ for art students, somatization-S $(\mathrm{M}=1.0 ;, \mathrm{SD}=.87$ for music and $\mathrm{M}=.89 ; \mathrm{SD}=.74$ for art students) negative self-concept-NI $(\mathrm{M}=1.03 ; \mathrm{SD}=.81$ for music and $\mathrm{M}=.79 ; \mathrm{SD}=.65$ for art students) according to Brief Symptom Inventory scores (see Table 1). 
Table 1. Descriptive Analyses for BFI Traits and BSI Symptoms of Music and Art Students

\begin{tabular}{|c|c|c|c|c|}
\hline \multirow[t]{2}{*}{ Variables } & \multicolumn{2}{|c|}{$\begin{array}{l}\text { Music Students } \\
(n=120 \text { for BFI) } \\
(n=107 \text { for BSI })\end{array}$} & \multicolumn{2}{|c|}{$\begin{array}{l}\text { Art Students } \\
(n=125 \text { for BFI }) \\
(n=112 \text { for BSI })\end{array}$} \\
\hline & Mean & SD & Mean & SD \\
\hline \multicolumn{5}{|l|}{ BFI } \\
\hline Extraversion & 5.83 & .63 & 5.82 & .56 \\
\hline Agreeableness & 3.82 & .53 & 3.82 & .53 \\
\hline Conscientiousness & 3.35 & .61 & 3.49 & .59 \\
\hline Neuroticism & 3.26 & .70 & 3.03 & .67 \\
\hline $\begin{array}{l}\text { Openness } \\
\text { to new experiences }\end{array}$ & 3.95 & .56 & 4.04 & .53 \\
\hline \multicolumn{5}{|l|}{$\begin{array}{l}\text { to new experiences } \\
\text { BSI }\end{array}$} \\
\hline Anxiety & 1.18 & .79 & .91 & .67 \\
\hline Depression & 1.54 & .94 & 1.31 & .83 \\
\hline Negative & 1.03 & .81 & .79 & .65 \\
\hline \multicolumn{5}{|l|}{ Self-concept } \\
\hline Somatization & 1.08 & .87 & .89 & .74 \\
\hline Hostility & 1.50 & .91 & 1.27 & 1.27 \\
\hline Total symptom disorder & 1.30 & .81 & 1.06 & 1.05 \\
\hline
\end{tabular}

Music students' scores were higher than that of art students in total symptom disorder $(\mathrm{M}=1.30 ; \mathrm{SD}=.81$ for music students and $\mathrm{M}=1.06 ; \mathrm{SD}=1.05$ for art students) and all sub dimensions of Brief Symptom Inventory (Table 1). The Mann-Whitney U test results for comparing the music and art students' psychological symptoms (Table 2) reflected that the scores of the music students' in total symptom disorder $\mu=4986.000 ; Z=2.146 ; p=.032$; in anxiety $\mu=4820.500$; $\mathrm{Z}=2.502 ; \mathrm{p}=.012$ and in negative self-concept $\mu=4924.500 ; \mathrm{Z}=2.280 ; \mathrm{p}=.023$ were found to be significantly higher $(\mathrm{p}<.05)$ in music students than in art students. However, although music students' scores were somewhat higher in terms of depression $\mu=5167.500 ; Z=1.760 ; p=.078$; somatization $\mu=5392.000 ; Z=1.282 ; p=.200$, and hostility $\mu=5195.00$; $\mathrm{Z}=1.703 ; \mathrm{p}=.089$, no statistically significant differences were observed.

Table 2. Mann-Whitney U Test results for comparison of Music and Art students according to BFI traits and BSI symptoms

\begin{tabular}{|c|c|c|c|c|c|c|}
\hline \multirow[b]{2}{*}{ Variables } & \multicolumn{2}{|c|}{ Music Students $(\mathrm{n}=\mathbf{1 2 0})$} & \multicolumn{4}{|c|}{ Art Students (n=125) } \\
\hline & Mean Rank & Sum of Ranks & Mean Rank & Sum of Ranks & $\mathbf{U} \mathbf{Z}$ & $\mathbf{p}$ \\
\hline \multicolumn{7}{|l|}{ BFI } \\
\hline Extraversion & 122.96 & 14755.00 & 123.04 & 15380.00 & $\begin{array}{l}7495.000 \\
Z=-.009\end{array}$ & .993 \\
\hline Agreeableness & 122.55 & 14706.50 & 123.43 & 15428.50 & $\begin{array}{l}7446.500 \\
Z=-.097\end{array}$ & .923 \\
\hline Conscientiousness & 113.76 & 13651.00 & 131.87 & 16484.00 & $\begin{array}{c}6391.000 \\
Z=-2.003\end{array}$ & $.045^{*}$ \\
\hline Neuroticism & 135.85 & 16302.00 & 110.66 & 13833.00 & $\begin{array}{c}5958.000 \\
Z=-2.785\end{array}$ & $.005^{*}$ \\
\hline Openness to new experiences & 117.10 & 14052.00 & 128.66 & 16083.00 & $\begin{array}{c}6792.000 \\
Z=-1.279\end{array}$ & .201 \\
\hline \multicolumn{7}{|l|}{ BSI } \\
\hline Anxiety & 120.95 & 12941.50 & 99.54 & 11148.50 & $\begin{array}{l}4820.500 \\
Z=-2.502\end{array}$ & $.012 *$ \\
\hline Depression & 117.71 & 12594.50 & 102.64 & 11495.50 & $\begin{array}{c}5167.500 \\
Z=-1.760\end{array}$ & .078 \\
\hline $\begin{array}{l}\text { Negative } \\
\text { Self-concept }\end{array}$ & 119.98 & 12837.50 & 100.47 & 11252.50 & $\begin{array}{c}4924.500 \\
Z=-2.280\end{array}$ & $.023^{*}$ \\
\hline Somatization & 115.61 & 12370.00 & 104.64 & 11720.00 & $\begin{array}{c}5392.000 \\
Z=-1.282\end{array}$ & .200 \\
\hline Hostility & 117.45 & 12567.00 & 102.88 & 11523.00 & $\begin{array}{l}5195.000 \\
Z=-1.703\end{array}$ & .089 \\
\hline Total symptom disorder & 119.40 & 12776.00 & 101.02 & 11314.00 & $\begin{array}{l}4986.000 \\
Z=-2.146\end{array}$ & $.032 *$ \\
\hline
\end{tabular}

$* \mathrm{p}<.05$

\section{Discussion and Conclusion}

The personality traits of music and art students were found to be similar when it came to extraversion, openness to new experiences, agreeableness, conscientiousness, and neuroticism respectively. Music students, however, were found to have significantly higher neuroticism scores than art students did, and art students had higher conscientiousness scores than music students did. Paralleling these results, extraversion (Dyce \& O’Connor, 1994; Feist, 1998; Steele \& Young, 
2011; Per \& Beyoğlu, 2011) and openness to new experiences (Dyce \& O'Connor, 1994; Feist, 1998; Gillespie \& Myors, 2000) have been reported as distinguishing characteristics of musicians and artists. However, some studies have found that features of introversion were higher in musicians (Kemp, 1996) and in artists in general (Dutta Roy, 1996). These contraversional results for extroversion and introversion for musicians argued in the related literature (Gillespie \& Myors, 2000) and interfered that introversion might be a personality temperament for higher level of musicians such as professional classical musicians, who require regular solitude in order to practice and maintain mastery of their instruments. Additonally, results of this study revealed that neuroticism scores of music students were higher than those of art students, echoing the study results of Gillespie \& Myors (2000) conducted with rock musicians. Based on the suggestions in the literature that neuroticism scores reflect emotionally instability (Booker, Feam \& Francis, 2001), the high neuroticism scores of the music students may be interpreted to mean that they are more emotionally changeable. Feist (1999) reported that artists are emotionally more flexible than individuals from other disciplines. Aghaei-Jeshvaghani, Jalalvand, and Zavari (2006) found that flexibility was higher in musicians when compared with different fields of arts that include poets, painters, actors, which supports this study results. On the other hand, it was found conscientiousness was higher among art students than among musicians. Consistent with these results, Gillespie and Myors (2000) found lower conscientiousness for musicians. This result may be explained by the idea that students who are studying art typically present their own works individually, a practice that can increase one's sense of conscientiousness. However, music students who perform in ensembles, in addition to playing solo performances, can decrease their sense of conscientiousness.

The results of this current study indicated that the psychological symptoms of art and music students were found to be similar across the categories of depression, hostility, anxiety, somatization and negative self-concept respectively. Additionally, the total symptom disorder, anxiety, and negative self-concept were significantly higher in music students than in art students. There are not many studies in the relevant literature related to the comparison of individuals in the field of music and art in respect to psychological symptoms. However, some earlier results showed that neuroticism tends to be high in musicians (Dyce and O'Connor, 1994; Gillespie \& Myors, 2000) and psychoticism in artists (Booker, Feam and Francis, 2001) when compared with non-artists. There was some evidence for the relationship between creativity and bipolar disorders (Vellante, Zucca, Preti et al., 2011), schizotypal-positive schizotypy and hypomania-manic symptoms (Rawlings \& Locarnini, 2008), and also higher substance-use, suicide rate, and mood disorders among artists (Papworth et al., 2008) . Additionally, there were results about the relationship between higher artistic scores which include painter, sculptor, graphic designer, and cartoonist students and psychoticism rather than neuroticism (Booker, Feam \& Francis, 2001). The limitations of this study does not allow the comparison of music and art students with respect to a number of psychopathological symptoms (bipolar disorders, schizotypal-positive schizotypy, hypomania-manic symptoms, etc.) that are frequently reported in academic literature. However, it was observed that the scores of anxiety, negative self-concept, and total symptom disorder, as well as the personality trait of neuroticism, were significantly higher in music students than in art students. In particular, the high scores for anxiety and negative self-concept among music students may be associated with the convention of having to perform in social environments, and with the idea that they have more requirements - such as being admired and appreciated - as emphasized in literature on performance anxiety (Yöndem, 2007; 2012). On the other hand, higher negative self-concept scores of music students suggest that they might have a greater need for admiration, a circumstance that may potentially affect one's choice to become a professional musician. Furthermore, being on stage and performing routinely for an audience may serve as a means of confronting and ameliorating one's anxiety. It should also be noted that features such as anxiety and negative self-concept are normal developmental characteristics specific to this student sample's young age. Additionally, these results can be interpreted through the idea that art students creating expressionist works may contribute their mental health and psychologically well-being as a catharsis.

In conclusion, there is a need for conducting more extensive research in order to identify both similar and different personality characteristics of music and art students. The determination of personality traits of individuals engaging in different art studies may help guiding students' professional orientation properly in earlier educational levels. On the other hand, it is also important to determine the specific psychological needs of music and art students during their undergraduate education since they will be mentor to children and adolescents while serving teaching activities in elementary, middle and/or high schools. Therefore, the increased psychological well-being of teacher candidates of music and art also holds potential to support healthy development in school aged children and adolescent. 


\section{References}

Aghaei-Jeshvaghani, A., Jalalvand, L., \& Zavari, G. A. (2006). A comparison of personality traits of artists and ordinary people. Radosa Personiba, Zinatnisko Rakstu Krajums, 4, 63-74, Riga, Latvia.

Baymur, F. (1994). Genel Psikoloji. İstanbul: İnk1lap Kitabevi.

Booker, B. B., Feam, M., \& Francis, L. J. (2001). The personality profile of artists. The Irish Journal of Psychology, 22(3-4), 277-281.

Burch, G. St. J., Pavelis, C., Hemsley, D. R., \& Corr, P. J. (2006). Schizotypy and creavity in visual artists. British Journal of Psychology, 97, 177-190. https://doi.org/10.1348/000712605X60030

Çakır, M. (2004). Mesleki Rehberlik, In A. Kaya (Eds.), Psikolojik Danışma ve Rehberlik (pp.137-168). Ankara: Anı yayıncilik.

Cameron, J. E., Duffy, M., \& Glenwright, B. (2014). Singers take center stage! Personality traits and stereotypes of popular musicians. Psychology of Music, 1-13. https://doi.org/10.1177/0305735614543217

Carson, S. H. (2011). Creativity and psychopathology: A shared vulnerability model. Canadian Journal of Psychiatry, 56(3), 144-153. https://doi.org/10.1177/070674371105600304

Clarke, J. R., \& Gipe, J. P. (1989). Psychological characteristics, teaching beliefs and teaching behaviors of artist/teachers. Paper presented at the Annual Meeting of NETWORK: Washington D.C., October 1989): Retrived from: https://eric.ed.gov/?id=ED314383

Cribb, C., \& Gregory, A. H. (1999). Stereotypes and personalities of musicians. The Journal of Musicans, 133(1), 104-114. https://doi.org/10.1080/00223989909599725

Drevdahl, J. E., \& Cattell, R. B. (1958) Personality and creativity in artists and writers. Journal of Clinic Psychology, April, 14(2), 107-111. https://doi.org/10.1002/1097-4679(195804)14:2<107::AID-JCLP2270140202>3.0.CO;2-T

Dutta, R. D. (1996). Personality model of fine artists. Creativity Research Journal, 9(4), 391-394. https://doi.org/10.1207/s15326934crj0904_10

Dyce, J. A., \& O'Connor, B. P. (1994). The personalities of popular musicians. Psychology of Music, 22, 168-173. https://doi.org/10.1177/0305735694222006

Eiduson, B. T. (1957). Artist and Non-artist: A Comparative Psychological Study. Unpublished doctoral dissertation. LA: University of California.

Evinç, S .G. (2004). Maternal personality characteristics, affective state, and psychopathology in relation to children's attention deficit and hyperactivity disorder and comorbid symptoms. Unpublished Master Thesis, Ankara: METU.

Feist, G. J. (1998). A meta-analysis of personality in scientific and artistic creativity. Personality and Social Psychology Review, 2(4), 290-309. https://doi.org/10.1207/s15327957pspr0204_5

Feist,G. (1999). The influence of personality on artistic and scientific creativity. In RJ. Sternberg (Ed.), Handbook of Creativity (pp.273-296). UK: Cambridge University Press.

Gillespie, W., \& Myors, B. (2000). Personality of rock musicians. Psychology of Music, 28, 154-165. https://doi.org/10.1177/0305735600282004

Götz, K. O., \& Götz, K. (1979). Personality characteristics of professional artists. Perceptual and Motor Skills, 49, 327-334. https://doi.org/10.2466/pms.1979.49.1.327

John, O. P., \& Srivastava, S. (1999). The Big Five trait taxonomy: History, measurement, and theoretical perspectives. In L. A. Pervin, \& O. P. John (Eds.), Handbook of personality: Theory and research (pp. 102-138). New York: Guilford Press.

Kemp, A. E. (1996). The musical temperament: Psychology and personality of musicians. New York, NY, US: Oxford University Press. https://doi.org/10.1093/acprof:oso/9780198523628.001.0001

Kuzgun, Y., \& Deryakulu, D. (2004). İçedönük ve dışadönük kişilik yapısı. Eğitimde Bireysel Farklılıklar. Ankara: Nobel Yayınevi

Ludwig, A. M. (1998). Method and madness in arts and sciences. Creative Research Journal, 11(2), 93-101. https://doi.org/10.1207/s15326934crj1102_1

Papworth, M. A., Jordan, G., Backhouse, C., Evans, N., Kent-Lemon, N., Morris, J., \& Winchester, K. J. G. (2008). Artists' vulnerability to psychopathology: Towards an integrative cognitive perspective. Journal of Creative Behavior, 42(3), 149-163. https://doi.org/10.1002/j.2162-6057.2008.tb01292.x 
Per, M., \& Beyoğlu, A. (2011) Personality types of students who study at the departments of numeric, verbal and fine arts in education faculties. Procedia Social and Behavioral Sciences, 12, 242-247. https://doi.org/10.1016/j.sbspro.2011.02.032

Rawlings, D., \& Locarnini, A. (2008). Dimentional schizotypy, autism, and unusual Word associations in artists and scientists. Journal of Research in Personality, 42, 465-471. https://doi.org/10.1016/j.jrp.2007.06.005

Savaşır, I., \& Şahin, N. H. (1997). Bilişsel Davranışçı Terapilerde Değerlendirme: Sık Kullanılan Ölçekler. Ankara: Türk Psikologlar Derneği Yayınları.

Steele, A. L., \& Young, S. (2011). A descriptive study of Myers-Briggs personality types of professional music educators and music therapists with comparisons to undergraduate majors. Journal of Music Therapy, 48(1), 55-73. https://doi.org/10.1093/jmt/48.1.55

Vallante, M., Zucca, G., Preti, A., Sisti, D. et all. (2011). Creativity and affective temperaments in non-clinical Professional artists: An empirical psychometric investigation. Journal of Affective Disorders, 135, 28-36. https://doi.org/10.1016/j.jad.2011.06.062

Vuust, P., Gebauer, L., Hansen, N. C., Jorgensen, S. R., Moller, A., \& Linnet, J. (2010). Personality influences career choice: Sensation seeking in professional musicians. Music Education Research, 12(2), 219-230. https://doi.org/10.1080/14613801003746584

Yöndem, Z. D. (2007). Performance anxiety, dysfunctional attitudes and gender in university music students. Social Behavior and Personality: an International Journal, 35(10), 1415-1426. https://doi.org/10.2224/sbp.2007.35.10.1415

Yöndem, Z. D. (2012). Physical, behavioral and cognitive characteristics of perceived performance anxiety in music students: A qualitative study. Education and Science, 37(166), 181-194.

Yöndem, Z. D. (2015). Personality. In M. Durak, E. Şenol Durak \& U. Kocatepe (Eds). Aklımın Akll: Psychsmart (pp256-276)Ankara: Nobel yayınevi

\section{Copyrights}

Copyright for this article is retained by the author(s), with first publication rights granted to the journal.

This is an open-access article distributed under the terms and conditions of the Creative Commons Attribution license which permits unrestricted use, distribution, and reproduction in any medium, provided the original work is properly cited. 